\title{
Prunus domestica 'Jojo' - Good Parent for Breeding of New Plum Cultivars Resistant to Plum pox Virus
}

\author{
Edward Żurawicz ${ }^{1}$, Kris Pruski $^{2}$, Marek Szymajda $^{1}$, Mariusz Lewandowski, Łukasz Seliga ${ }^{1} \&$ \\ Tadeusz Malinowski ${ }^{1}$ \\ ${ }^{1}$ Research Institute of Horticulture, Skierniewice, Poland \\ ${ }^{2}$ Department of Plant \& Animal Sciences, Dalhousie University, Truro, Canada \\ Correspondence: Edward Żurawicz, Research Institute of Horticulture, Konstytucji 3 Maja 1/3, Skierniewice \\ 96-100, Poland. Tel: 48-46-834-54-25. E-mail: Edward.Zurawicz@inhort.pl
}

Received: May 21, 2013 Accepted: June 27, 2013 Online Published: August 15, 2013

doi:10.5539/jas.v5n9p1 URL: http://dx.doi.org/10.5539/jas.v5n9p1

\begin{abstract}
The possibility of obtaining new varieties of plum resistant to the Plum pox virus by using traditional breeding methods with resistant lines was assessed in 2007-2012. The source of the resistance was the plum variety 'Jojo' that shows a mechanism of local hypersensitivity, which results in the whole plant being resistant. The assessment covered 435 Prunus domestica seedlings from eleven $\mathrm{F}_{1}$ hybrid families which had been obtained with traditional breeding methods by crossing the variety 'Jojo' with other plum varieties. The results showed that the variety 'Jojo', used either as a maternal or paternal parent, can be a valuable parental form in plum breeding programmes aimed at obtaining varieties resistant to the sharka disease. Three highly hypersensitive genotypes were obtained: \# 4, \# 48, and \# 186, and an additional 14 were selected for further evaluation. Their production value will be assessed in the coming years.
\end{abstract}

Keywords: Prunus domestica, Plum pox virus, hypersensitivity, breeding for resistance, plum cultivars

\section{Introduction}

The sharka disease, caused by the Plum pox virus (PPV), is a very serious disease of stone fruit trees, especially plum trees (Prunus domestica L.). It causes major damage in the form of deterioration in the quality of the fruit and reduction the fruit yield. The disease was first observed in regions of Macedonia and Bulgaria around 1915 (Atanassov, 1932). PPV is transmitted with the plant material during budding and grafting. In orchards, it is further spread by aphids from the diseased trees to healthy ones. It is estimated that over the past 30 years, the losses caused by sharka worldwide can exceed 10 billion euros (Cambra, Capote, Myrta, \& Llácer, 2006). Plum pox virus isolates belonging to strain D were also detected in US (Levy et al., 2000) and Canada (Thompson et al., 2001). Eradication efforts in Canada were only partially effective, and additionally isolates of two other strains were identified: PPV-W (James \& Varga, 2005) and PPV-Rec (Thompson et al., 2009). In Poland, the symptoms of sharka were first observed in 1959 in the sub-Carpathian region (Pieniążek, 1962; Szczygiel, 1962). So far, the dominant strain of the virus in Poland has been strain D, but occasionally one can come across strain Rec (Malinowski, 2006). Numerous varieties of plum are well-suited for cultivation in Poland's natural environment. However, because of their high sensitivity to the Plum pox virus, the useful life of a plum orchard in this country rarely exceeds $10-15$ years.

Plants infected with the virus remain less productive and are sources of secondary infections, as there are no treatments that could help combat the disease in the infected trees. Due to a non-persistent mode of virus transmission by aphids, controlling the vectors is not effective in preventing the virus from being spread (Kegler, Fuchs, Gruntzig, \& Schwarz, 1998). The fight against sharka thus involves early identification of the disease in the orchard and removal of the affected trees. The most effective method of limiting the damage caused by the Plum pox virus would be to use resistant varieties. Unfortunately, within $P$. domestica there has been no success as yet in finding the source of genes providing complete resistance (immunity) to the virus, and/or to aphids (Hartman, 1998a; Hartman \& Petruschke, 2000; Hartman \& Neumüller, 2006). Effective field resistance of the whole plant to aphid transmitted virus infection can be obtained by employing the mechanism of hypersensitivity. Rapid death of the cells around the site of penetration by the virus into leaf tissue results in the localization of the infection and eventual destruction of the virus (Hartmann, 1998b). Genotypes showing this type of resistance remain free from 
the sharka virus under the natural conditions in which the pressure of the pathogen has been high for a number of years (Kegler, Grntzig, \& Fuchs, 1994; Neumüller \& Hartmann, 2008). One of the sources of this type of resistance in $P$. domestica is the variety 'Jojo' bred in Germany. The aim of the work described here was to assess the possibility of breeding resistant varieties of plum by the traditional cultivation method using the variety 'Jojo' as a parental form resistant to the Plum pox virus.

Assessment of seedlings for resistance/susceptibility to sharka in field conditions requires many years of testing, and ambiguous results are often obtained (Neumüller, 2011). Therefore, in plum breeding for resistance it is necessary to employ methods of artificial inoculation to enable rapid selection of seedlings in terms of their sensitivity to the sharka virus.

\section{Methods and Materials}

The experiments were carried out at the Research Institute of Horticulture (formerly Research Institute of Pomology and Floriculture) in Skierniewice, Poland. The plant material consisted of $P$. domestica seedlings from 11 families of $F_{1}$ hybrids ( 14 crossing combinations) (Table 1 ). They were obtained by crossing the variety 'Jojo' with other plum varieties and by collecting seeds from self- or open-pollinated variety 'Jojo' trees. The cross-fertilizations were carried out in the years 2004 to 2006. The resulting seeds produced 657 seedlings, which were planted in two plots in the Experimental Orchard in Dąbrowice near Skierniewice (central Poland). The assessment of the resistance of the seedlings to sharka was carried out in 2007-2012. The method used to test the seedlings was that described by Kegler et al. (1994), with slight modifications. First, at the beginning of March (years 2006-2011), scions taken from a tree of the Common Prune heavily infected with PPV-D (Dideron), a strain commonly found in Poland (Malinowski \& Zawadzka, 2005), were grafted onto healthy Prunus cerasifera var. divaricata rootstocks to serve as a sharka-infected interstem. In the second half of March (2006-2011), the grafted plants were transplanted to 8-litre plastic containers filled with compost soil, and placed in an insect-proof screenhouse. In mid-March of the following year (years 2007-2012), on the shoot growing out of the sharka-infected interstem, grafts were made with scions taken from the plum seedlings selected for testing.

Table 1. Parental forms of the plum seedlings under assessment and the results of DAS-ELISA in the first stage of testing (Skierniewice, 2007-2011)

\begin{tabular}{|c|c|c|c|c|c|c|}
\hline \multirow{3}{*}{ No. } & \multirow{3}{*}{$\begin{array}{l}\text { Crossing } \\
\text { combination } \\
\text { number }\end{array}$} & \multirow{3}{*}{ Crossbred parental forms } & \multirow{3}{*}{$\begin{array}{l}\text { Number of } \\
\text { seedlings } \\
\text { obtained }\end{array}$} & \multicolumn{3}{|c|}{$\begin{array}{c}\text { Genotypes tested with } \\
\text { DAS-ELISA * }\end{array}$} \\
\hline & & & & & & \\
\hline & & & & Total tested $* *$ & $\begin{array}{c}\text { Result } \\
(+)\end{array}$ & $\begin{array}{l}\text { Result } \\
(-)\end{array}$ \\
\hline 1 & 2004-09 & Jojo $\times$ Čačanska Rana & 160 & 109 & 59 & 50 \\
\hline 2 & $2004-10$ & Jojo $\times$ Kalipso & 51 & 43 & 20 & 23 \\
\hline 3 & 2004-11 & Jojo $\times$ SPJ & 34 & 21 & 17 & 4 \\
\hline 4 & $2004-12$ & Jojo $\times$ open pollination & 4 & 4 & 1 & 3 \\
\hline 5 & $2004-36$ & Jojo $\times$ self-pollination & 3 & 3 & 1 & 2 \\
\hline 6 & $2005-06$ & Jojo $\times$ Čačanska Rana & 72 & 58 & 54 & 4 \\
\hline 7 & $2005-07$ & Jojo $\times$ Kalipso & 9 & 9 & 7 & 2 \\
\hline 8 & $2005-08$ & Jojo $\times$ SPJ & 103 & 21 & 21 & 0 \\
\hline 9 & 2005-09 & Jojo $\times$ Mr Hative & 48 & 28 & 23 & 5 \\
\hline 10 & $2004-35$ & Common Prune $\times$ Jojo & 4 & 4 & 3 & 1 \\
\hline 11 & $2005-03$ & Amers $\times$ Jojo & 11 & 9 & 8 & 1 \\
\hline 12 & $2005-12$ & Mr Hative $\times$ Jojo & 93 & 86 & 58 & 28 \\
\hline 13 & $2005-14$ & SPJ $\times$ Jojo & 49 & 39 & 29 & 10 \\
\hline 14 & $2005-17$ & Sultan $\times$ Jojo & 16 & 1 & 1 & 0 \\
\hline \multicolumn{3}{|c|}{ Grand total } & 657 & 435 & 302 & 133 \\
\hline
\end{tabular}

* each genotype was grafted on one infected interstem.

** if the shoots were dying, grafting was repeated in subsequent years. 
The assessment of the resistance of the seedlings to the sharka virus was divided into two stages. In the first stage, each seedling selected for testing was grafted onto a single interstem infected with PPV-D. From the shoot growing out of that graft, leaf samples were collected for DAS-ELISA tests. The seedlings whose grafts produced a poorly growing or wilting shoot with not enough leaves for DAS-ELISA tests were grafted on infected interstems again in subsequent years. In the first stage, 435 seedlings were tested in this way (Table 1). Most of the seedlings were found to be sensitive (but not hypersensitive) to the sharka virus already during the first stage of assessment, as evidenced by severe symptoms of the disease on the leaves and a high concentration of the virus in the leaves revealed by ELISA. Those seedlings were not tested again. Genotypes for which wilting of shoots was observed consistently in three-four years were selected for the second stage of assessment in which each of them was tested on 12 infected interstems in subsequent years. This method was also used to test several genotypes for which DAS-ELISA results were negative. The DAS-ELISA tests were done separately for each plant within each genotype being assessed. After the assessment, all of the plants, from the 1 st and 2 nd stage of testing, were removed from the insect-proof enclosure and destroyed.

\section{Results and Discussion}

Observations during the first weeks after grafting revealed the wilting of shoots growing out of the grafts of seedlings of the genotypes \# 4 (Common Prune $\times$ Jojo), \# 48 (Jojo $\times$ Čačanska Rana) and \# 186 (Jojo $\times$ SPJ) $($ Table 2). The few shoots that had not wilted showed abnormal growth. This was an indication that the three genotypes were hypersensitive to the sharka virus. Similar behaviour was observed in the control variety 'Jojo', whose shoots also wilted a few weeks after grafting, while those that kept growing (in 2012) had growth disorders. The ELISA results for the plants of the genotypes Nos. 4, 48, and 186, and also the variety 'Jojo', were negative (absence or very low concentration of the virus). According to Kegler et al. (1994) and Hartmann \& Petruschke (2000), shoots of highly hypersensitive genotypes wilt completely, or their growth tips die a few weeks after being grafted on rootstocks heavily infected with PPV. However, the sharka virus in those shoots cannot be detected with ELISA (Neumüller, Hartman, \& Stösser, 2007). Moreover, the wilting or abnormal growth of shoots can take a different course depending on the genotypes tested because there are different degrees of hypersensitivity (Neumüller, Hartman, \& Stösser, 2005, Neumüller \& Hartmann, 2008).

Table 2. Survival of plants and the results of DAS-ELISA within the genotypes after grafting each of them onto 12 interstems infected with PPV-D (Skierniewice, 2008-2012)

\begin{tabular}{|c|c|c|c|c|c|c|c|}
\hline \multirow{2}{*}{ Parental forms } & \multirow{2}{*}{$\begin{array}{c}\text { Genotype } \\
\text { number }\end{array}$} & \multirow{2}{*}{ Year } & \multicolumn{2}{|c|}{ Number of dead plants } & \multicolumn{3}{|c|}{$\begin{array}{l}\text { Plants tested with } \\
\text { ELISA }\end{array}$} \\
\hline & & & $\begin{array}{c}\text { Before } \\
\text { ELISA * }\end{array}$ & $\begin{array}{c}\text { After } \\
\text { ELISA }\end{array}$ & $\begin{array}{l}\text { Total } \\
\text { tested }\end{array}$ & $\begin{array}{c}\text { Result } \\
(+)\end{array}$ & $\begin{array}{c}\text { Result } \\
(-)\end{array}$ \\
\hline \multirow[t]{2}{*}{ Jojo (HS genotype control) } & - & 2010 & 12 & 0 & 0 & 0 & 0 \\
\hline & - & 2012 & 5 & 0 & $7 * *$ & 0 & 7 \\
\hline \multirow[t]{5}{*}{ Common Prune $\times$ Jojo } & 4 & 2008 & 11 & 0 & 1 & 0 & 1 \\
\hline & & 2009 & 11 & 0 & 1 & 0 & 1 \\
\hline & & 2010 & 10 & 0 & 2 & 0 & 2 \\
\hline & & 2011 & 10 & 1 & 2 & 0 & 2 \\
\hline & & 2012 & 6 & 0 & 6 & 0 & 6 \\
\hline \multirow[t]{2}{*}{ Jojo $\times$ Čačanska Rana } & 48 & 2011 & 9 & 0 & 3 & 0 & 3 \\
\hline & & 2012 & 3 & 0 & 9 & 0 & 9 \\
\hline \multirow[t]{2}{*}{ Jojo $\times$ SPJ } & 186 & 2011 & 11 & 1 & 1 & 0 & 1 \\
\hline & & 2012 & 9 & 0 & 3 & 0 & 3 \\
\hline \multirow[t]{2}{*}{ Jojo $\times$ Cačanska Rana } & 43 & 2011 & 1 & 0 & 11 & 0 & 11 \\
\hline & & 2012 & 6 & 0 & 6 & 0 & 6 \\
\hline \multirow[t]{4}{*}{ Jojo $\times$ Čačanska Rana } & 60 & 2009 & 5 & 0 & 7 & 0 & 7 \\
\hline & & 2010 & 3 & 3 & 9 & 1 & 8 \\
\hline & & 2011 & 5 & 0 & 7 & 0 & 7 \\
\hline & & 2012 & 2 & 0 & 10 & 1 & 9 \\
\hline \multirow[t]{2}{*}{ Jojo $\times$ Kalipso } & 218 & 2011 & 1 & 0 & 11 & 0 & 11 \\
\hline & & 2012 & 1 & 0 & 11 & 0 & 11 \\
\hline
\end{tabular}

* The plants had not developed a sufficient number of leaves for the ELISA test.

** The developing shoots showed severe growth disorders. 
The wilting of shoots was also observed in 14 genotypes in the first stage of tests, repeated in three or four different years. According to Neumüller and Hartmann (2008) and Neumüller (2011), testing of plum genotypes under greenhouse conditions in three replications (three plants) is sufficient to assess their sensitivity/resistance to PPV. In our tests, although the genotypes were grafted each year on a single infected interstem, the recurring wilting of their shoots in several different years indicated that those genotypes were hypersensitive to PPV-D. In the coming years, those genotypes will be tested on a larger number of plants. Seventeen selected plum genotypes will also be tested for hypersensitivity response to PPV-Rec and possibly other less common strains.

Table 2 contains also the results of the second stage of assessment for three other genotypes: \# 43, \# 60, and \# 218, which did not produce the hypersensitivity response, but the virus was either not found in the developing shoots or was found in one plant out of the 12 tested. Those genotypes will be subjected to further characterization.

\section{Conclusions}

The results of the experiments presented here are the first successful results in Poland of research into the possibility of obtaining plum varieties resistant to the sharka virus using traditional breeding methods. They show that the locally hypersensitive variety 'Jojo', used either as a maternal or paternal parent, can be a valuable genplasm source in plum breeding programmes aimed at obtaining locally hypersensitive varieties that will be resistant to the sharka disease. In the coming years, the three highly hypersensitive (resistant) genotypes \# 4, \# 48, and \# 186, as well as fourteen others selected on the basis of the first stage of assessment, will be evaluated in terms of fruit quality and yield potential. They too, will be used in plum breeding for resistance to the Plum pox virus.

\section{References}

Atanassov, D. (1932). Plum Pox: A new virus disease. Annals of the University Sofia, Faculty of Agriculture and Silviculture, 11, 49-69.

Cambra, M., Capote, N., Myrta, A., \& Llácer, G. (2006). Plum pox virus and the estimated costs associated with sharka disease. Bulletin OEPP/EPPO Bulletin, 36, 202-204.

Hartmann, W. (1998a). Züchtung scharkaresistenter Pflaumen- und Zwetschensorten. Erwerbsobstbau, 40, 8-12.

Hartmann, W. (1998b). Breeding of plums and prunes resistant to Plum pox virus. Acta Virologica, 42, 230-232.

Hartmann, W., \& Neumüller, M. (2006). Breeding for resistance: breeding for Plum pox virus resistant plums (Prunus domestica L.) in Germany. EPPO Bulletin, 36, 332-336. http://dx.doi.org/10.1111/j.1365-2338.2006.01010.x

Hartmann, W., \& Petruschke, M. (2000). Sharka resistant plums and prunes by utilization of hypersensitivity. Acta Horticulturae, 538, 391-395.

Jakubowski, T. (1998). Breeding of plums cultivars in Poland. Acta Horticulturae, 478, 151-154.

James, D., Varga, A. (2005). Nucleotide sequence analysis of Plum pox virus isolate W3174: evidence of a new strain. Virus Research, 110(1-2), 143-50. http://dx.doi.org/10.1016/j.virusres.2005.02.004

Kegler, H., Fuchs, E., Gruntzig, M., \& Schwarz, S. (1998). Some results of 50 years of research on the resistance to plum pox virus. Acta Virologica, 42, 200-215.

Kegler, H., Grntzig, M., \& Fuchs, E. (1994). A glasshouse test for detecting resistance of plum genotypes to Plum pox virus. Acta Horticulturae, 359, 52-158.

Levy, L., Damsteegt, V., \& Welliver, R. (2000). First Report of Plum Pox Virus (Sharka Disease) in Prunus persica in the United States. Plant Disease, 8, 202. http://dx.doi.org/10.1094/PDIS.2000.84.2.202B

Malinowski, T. (2006). Plum pox virus (PPV) in Poland. EPPO Bulletin, 36, 212-213. http://dx.doi.org/10.1111/j.1365-2338.2006.00962.x

Malinowski, T., \& Zawadzka, B. (2005). Forty-two years of plum pox presence in Poland. Phytopathologia Polonica, 36,131-136.

Neumüller, M. (2011). Fundamental and applied aspects of plum (Prunus domestica) breeding. Global Science Books. Fruit. Vegetable and Cereal Science and Biotechnology, 5(Special Issue 1), 139-156.

Neumüller, M., \& Hartmann, W. (2008). The phenotypically quantitative nature of hypersensitivity of European plum (Prunus domestica L.) against the Plum pox virus and its description using the hypersensitivity index. Horticultural Science, 35, 50-64. 
Neumüller, M., Hartmann, W., \& Stösser R. (2005). Hypersensitivity of the European plum (Prunus domestica L.) against the sharka virus (Plum Pox Virus) as promising mechanism of resistance. Phytopathologia Polonica, $36,77-83$.

Neumüller, M., Hartmann, W., \& Stösser, R. (2007). Inheritance of hypersensitivity of European Plum (Prunus $\times$ domestica L.) against Plum Pox Virus (PPV). Acta Horticulturae, 734, 69-76.

Pieniążek, S. A. (1962). Survey on fruit tree virus diseases present in Poland. 5th European Symposiumon Fruit Tree Virus Diseases, Bologna.

Szczygieł, A. (1962). Pojawienie się w Polsce groźnej choroby wirusowej szarki Prunus virus-7 [The appearance of dangereous sharka virus disease in Poland]. Ochrona Roślin, 1-2, 14-17.

Thompson, D., McCann, M., MacLeod, M., Lye, D., Green, M. \& James, D. (2001). First report of plum pox potyvirus in Ontario, Canada. Plant Disease, 85, 97. http://dx.doi.org/10.1094/PDIS.2001.85.1.97C

Thompson, D., Varga, A., De Costa, H., \& Birch, C. (2009). First Report of Plum pox virus Recombinant Strain on Prunus spp. in Canada. Plant Disease, 93, 674. http://dx.doi.org/10.1094/PDIS-93-6-0674A

\section{Copyrights}

Copyright for this article is retained by the author(s), with first publication rights granted to the journal.

This is an open-access article distributed under the terms and conditions of the Creative Commons Attribution license (http://creativecommons.org/licenses/by/3.0/). 